for al religion og etik og sætter derved mennesket i Guds sted. - Kun en anskuelse, der indser dette og således gør sig klart at mennesket kun er "Guds Statholder", som Grundtvig udtrykker det, er forenelig med den kristne tro. Videnskaben udtrykker ét synspunkt, religionen et andet i den tilværelse, vi hverken er herrer over eller viljeløse og ansvarsløse dele af. Sådan var Grundtvigs opfattelse allerede i den filosofiske betragtning "Om Mennesket i Verden" fra 1817. I 1833 kaldte han den "den mosaisk-christelige Anskuelse af Menneskelivet i alle dets Retninger og alle dets Yttringer" - altså også videnskab og tro. Begrebet videnskab (forskelligt fra "Vidskab", dvs. filosofi) omfattede for Grundtvig ikke blot naturvidenskab og humanistiske videnskaber, men også teologi. Hvis denne videnskab formulerer et gudsbegreb som den sætter i Guds sted, så er der ingen Gud; så er mennesket sin egen gud. Men det er "kun Fjas" med en sådan gudsvidenskab, skrev Grundtvig allerede i 1816 (Danne-Virke I).

Grundtvig har for så vidt forudsagt - og forlængst modsagt - det udtryk i Nietzsches "Also sprach Zarathustra", at "Gud er død". Han vidste - af sin egen personlige erfaring i 1810-1811 - at Gud lever. Men han forstod først i 1814, da han formulerede den filosofiske grund under sit historiesyn, at Faderen bor i et utilgængeligt lys, dvs. er uerkendelig for al menneskelig fornuft. Også for vor filosofi eller vidskab. Vi kan kun se hans "Spor" i skaberværket og historien og forestille os ham som skaberen og opretholderen. - Men vi kan tro på hans Ord, som er åbenbaret os gennem Jesus, som hans disciple og apostle kaldte Kristus. Det er denne tro, der meddeles os gennem dåben.

\title{
Grundtvig på normaldansk
}

\author{
Af William Michelsen
}

Helge Grell: Skaberånd og folkeånd. En undersøgelse af Grundtvigs tanker om folk og folkelighed og deres forhold til hans kristendomssyn. Forlaget Anis, Arhus 1988. 346 sider.

Menneske først, kristen så. Helge Grells Grundtvig-disputats til debat. Red. af Jens Holger Schjørring, forfatterne og forlaget Anis, Arhus 1988. 101 sider.

Hvis man er træt af sine forsøg på at læse Grundtvigs prosa - enten fordi han bruger sine egne mærkelige ord i st.f. de hævdvundne fremmedord i det filosofiske kunstsprog, eller fordi man taber tråden i hans lange sætningskæder så kan det anbefales at læse denne bog. Helge Grell har præsteret det kunststykke at oversætte Grundtvigs teologi til dansk normalprosa. Ingen har herefter den undskyldning for ikke at kende ham, at han er ulæselig bortset fra 
sine salmer - som dog ogs̊̊ kan have deres knuder og et billedsprog, der forekommer en for fjernt eller alt, alt for hverdagsligt. Man vil da opdage - når man er kommet over de første kapitler om de tyske forfattere, som Grundtvig afviste - at vi her har en højst original skabelsesteologi, hvis originalitet simpelthen kommer fra Bibelen. Det kan da blive nødvendigt at supplere sin læsning med Grells første bog "Skaberordet og billedordet. Studier over Grundtvigs teologi om ordet." (København 1980, anmeldt i Grundtvig-Studier 1982.)

Grell har i disse afhandlinger vist, at der var god sammenhæng i Grundtvigs tænkning fra 1810 til 1865, også når den drejede sig om folk og folkelighed. Grundtvig var ikke en nationalist, der misbrugte kristendommen til at tordne mod Tyskland og tyskerne, men en god teolog, hvis syn på mennesket og menneskelivet gik ud fra, at mennesket er skabt i Guds billede. Grell indrømmer i sit svar til sine kritikere, at Grundtvig overdriver under indtryk af de to slesvigske krige; men der er ikke tale om nogen afsporing af grundtankerne $\mathrm{i}$ hans menneskesyn, hævder Grell. Man kan i denne bog finde den røde tråd i Grundtvigs umådelige forfatterskab. Grundtvig-citaterne er forholdsvis få og korte, og de er langtfra på forhånd velkendte.

Det er lykkedes Helge Grell at give en historisk fremstilling af udviklingen i Grundtvigs tænkning, som uden at forenkle eller forfalske den gør det muligt for nulevende mennesker at følge og forstå den. Hvilket er en bedrift, hvad professor dr. theol. A. Pontoppidan Thyssen med rette kalder det $i$ sin opposition. Hans indlæg er trykt tillige med to andre opponenters og to indlæg af teologer, der ikke var til stede ved selve disputatsen. Ialt fem indlæg foruden Helge Grells svar.

Blandt disse indlæg lægger man særlig mærke til et af Kaj Thaning, hvis opfattelse af den samme tænkning får en helt igennem redelig og loyal behandling af Grell, koncentreret i noterne. Thanings svar og Grells replik har en karakter, der viser den gensidige respekt. Det er en fornøjelse at læse denne smukke dialog, der slutter den lille bog. Det fremgår iøvrigt af Jens Holger Schjørrings opposition, at hele dette noteapparat oprindelig ikke hørte med til bogen. Man må være taknemmelig over, at det kom med, fordi bogen først derved blive mulig at placere i Grundtvig-debatten. Det var desværre ikke tilfældet med hans første afhandling "Skaberordet og billedordet". Nu ser man, at bogen er en begivenhed i Grundtviglitteraturen.

Grundtanken i begge Grells afhandlinger er den, at ligesom mennesket er skabt i Guds billede ved hans skaberord, er menneskets evne til at tale et billede af Guds skaberord, således at der er en "parallel" mellem virkningerne af menneskeordet og Guds skabende ord. Virkningen beror på den ånd, der er i ordet. Deraf titelen på den her anmeldte afhandling "Skaberånd og folkeånd."

Den parallel, Grundtvig her drager mellem Guds skabende ord og det nyskabte menneskes taleevne, er naturligvis meget dristig. Luther ville aldrig have vovet noget sådant; for ham var al viden om det nyskabte menneske tabt ved syndefaldet. Grell siger derfor med rette:

"En virkelig kritik af Grundtvigs syn på folkelighed og ganske særlig dansk folkelighed beskæftiger sig kun med udenværkerne, hvis den standser op ved hans kærlighedserklæringer til det danske folk og hans tro på, at det er i Guds hånd. Der, hvor kritikken skal sætte ind, er over for hans skabelses- og ordteologi." (S. 214). 
Det ejendommeligste ved denne bog er den lidenskabsløshed, hvormed den er skrevet. Først da forfatteren var kommet nær ved afslutningen af sit arbejde, gik det op for ham, at det kunne betragtes som et modskrift mod Thanings disputats "Menneske først -" (1963), som har gjort Grundtvig aktuel for efterkrigstidens ungdom. Men hos Grell drejer det sig ikke om for eller imod Thaning. Det drejer sig om, hvad Grundtvig virkelig har tænkt. - Mindre om, hvorvidt Grundtvig havde ret i sin teologi. Man kunne derfor vente, at dette spørgsmål var taget op i oppositionsindlæggene mod Grell. Men det er ikke tilfældet. Man drøfter, om han var skabelsesteolog, frelseshistorieteolog eller treenighedsteolog - skønt det er klart, at han var alle tre dele. Thaning mener stadig, at der sker et klart brud i Grundtvigs arbejde med Indledningen til Nordens Mythologi 1832, og at der er et tydeligt skel mellem Grundtvigs prædikener før og efter 1832 , hvilket man må give ham ret i. Men spørgsmålet er, om denne ændring i Grundtvigs holdning over for samtiden førte til et nyt kristendomssyn, og det er dette spørgsmål, Grell må besvare med et nej. Men det er ikke hans hensigt at stille det mosaisk-kristelige syn på menneskelivet op "som stopklods" for en fortsat debat, således som Thaning har antydet. Grell slutter:

"Det kan aldrig være klart formulerede opfattelser, der, selvom de afslører modsætninger, făr en debat til at ophøre. Den afspores derimod som følge af mangel på tydeligt markerede grænser. Thanings egen betydning i Grundtvigforskningen er et fint eksempel på netop dette. Hans klart formulerede synspunkter vedrørende Grundtvigs værk og betydning har ført til en endnu ikke afsluttet debat, og jeg kan kun tilslutte mig hans ønske om, at også mine afhandlinger kan medvirke til, at Grundtvig-debatten aldrig hører op som en væsentlig del af vor folkelighed", siger Grell.

Heri må man under alle omstændigheder give Grell ret. Netop ved at fastholde den mosaisk-kristelige "Anskuelse af Menneskelivet $\mathrm{i}$ alle dets Retninger og alle dets Yttringer" balancerer Grundtvig i sin tænkning på grænsen mellem hedenskab og kristendom, og han véd det selv. Men det var langtfra alle $\mathrm{i}$ hans omgivelser, der forstod det.

Heri ligger en væsentlig årsag til, at grundtvigianismen i folkelig forstand blev et så omstridt fænomen. Når selv hans kirkelige medkæmper fra 1825, Rudelbach, allerede i 1847 sluttede sig til anklagen mod Grundtvig for at sammenblande folkelighed og kristendom, viser det, at kritikken ikke var overfladisk. Grundtvigs svar på kritikken har været svært at forstå. Grells disputats viser imidlertid klart, hvad Grundtvigs tænkning bunder i, nemlig Bibelens ord om, at mennesket er skabt i Guds billede. Denne tanke, som er grundlaget for hans tænkning allerede i Verdens Krønike 1814, blev i tiden omkring de to slesvigske krige, dvs. fra 1844 til 1865, udbygget på en så ejendommelig måde, at den først nu kan forstås helt klart.

Der er ikke tale om nogen. omvendelse fra kristendom til hedenskab (eller "menneskelivet" eller danskheden), men om en gradvis afklaring af, hvad det ifølge Grundtvig betyder, at mennesket er skabt i Guds billede: Gud har i kraft af sin And skabt verden med de $\mathrm{i}$ Bibelens første kapitel anførte ord og til sidst menneskene, for at de skulle ligne ham og herske over de skabte levende 
væsener, planter og dyr. Han skabte dem som mand og kvinde i sit billede. Ifølge Bibelens andet kapitel skabte han først manden Adam af jord og indblæste ham sin livsånde, så at mennesket blev en levende sjæl, altså bestående af jord og ånd, der i kraft af Guds livsånde blev levende. Derpå lod Gud Adam kende alle dyrene; men Adam ville ikke leve sammen med nogen af dem. Han fik imidlertid kundskab om alle de planter og dyr, som Gud havde skabt. Kun ét træ fik han ikke kundskab om af Gud: træet til kundskab om godt og ondt. Da nu Adam ikke ville leve sammen med noget af de dyr, Gud havde skabt, lod Gud Adam falde i en dyb sovn og skabte under denne søovn kvinden Eva af et af Adams ribben. Og da Adam vågnede og så hende, svarede han straks Gud: "Ja, denne gang er det kød af mit kød og ben af mine ben. Hun skal kaldes mand-inde, dvs. det kvindelige menneske, og blive moder til alle mennesker." - Således er efter min opfattelse Grundtvigs tydning af fortællingen om menneskets skabelse i Bibelens andet kapitel.

Og det er denne fortælling om kvindens skabelse, der er udgangspunkt for Grundtvigs udbygning af sin bibelske menneskeopfattelse: kvinden er det fuldkomne menneske, som Gud skabte sidst af alle levende væsener, og som er moder til alt levende. Denne udbygning af Grundtvigs menneskesyn skete samtidig med hans forelskelse - først i den sidste af "Smaafruerne", fru Luise Hennings, og dernæst i fru Marie Toft, som blev hans anden hustru, og som kom til helt at overskygge ikke blot de tre "Smaafruer", men også hans egen første hustru, Lise Blicher. Ægteskabet med fru Marie Toft kom kun til at vare 3-4 år, men kom til afgørende at præge den sidste fase af Grundtvigs udvikling, også under hans 3. ægteskab med fru Asta Reedtz.

Det farlige i hele denne menneskeopfattelse - og den deraf udsprungne opfattelse af de folk, som udviklede sig deraf - er, som man let ser, at den intet hensyn tager til den begivenhed, der fortælles i Bibelens 3. kapitel, om slangen, der fristede Eva til at spise af træet til kundskab om godt og ondt sammen med Adam, hvorved de opdagede den forskel, der er mellem mand og kvinde, som de derpå forsøgte at skjule, men forgæves: Gud forstod straks, hvad der var sket, og hvad følgen måtte blive, nemlig døden, som han havde forudsagt Adam: adskillelsen fra livstræet og livskilderne $\mathrm{i}$ den verden, Gud havde skabt, og hvori alt var godt. Man kalder denne begivenhed "syndefaldet", skønt dette ord ikke bruges i fortællingen, men skyldes de tanker, hvormed man har fortolket den. Grundtvig holder sig imidlertid til Bibelen, hvor han fortolker fortællingen i sin Verdens Krønike 1814. Han analyserer slangens ord: "Det er ikke sandt, hvad Gud har sagt, at I skal dø. Men Gud véd, at I ved at spise af denne frugt vil blive lige så kloge som han og kende godt og ondt," hvilket var løgn. Men Adam og Eva troede altså mere på slangens ord end på Guds ord. De ønskede at blive lige så kloge som Gud på godt og ondt, og lod sig derfor friste til at spise af den frugt, som Gud havde advaret dem imod som dødelig, dvs. dødbringende. De misbrugte deres fornuft, siger Grundtvig, og blev derved selv dødelige.

Det mærkeligste ved fortællingen i Bibelen er imidlertid ikke dette forløb, som ethvert menneske har let ved at genkende fra sit eget liv, men Guds ord til slangen, som fristede Eva og Adam: "Kvindens afkom skal knuse dit hoved, omend du bider ham i hælen." - Det er disse ord, alle kristne finder opfyldt i Jesu evangelium. $\mathrm{Og}$ det er dette evangelium, som er indholdet og grundstenen for 
hele Grundtvigs kristne prædiken og salmedigtning. - Hvorledes kunne Grundtvig nu forene denne kristne tro med en menneskeopfattelse, der tilsyneladende intet hensyn tog til, at mennesket havde misbrugt sin fornuft ved at bilde sig ind at kende både godt og ondt og således sætte sig i Guds sted?

Herom handler Grundtvigs tænkning, der begyndte i 1813 med forelæsningsudkastet "Om Menneskets Vilkaar", og hvis første resultater offentliggjordes i tidsskriftet Danne-Virke 1816-19, men som fortsattes resten af Grundtvigs liv og ligger bag ved hele hans salmedigtning. Den udtryktes imidlertid også i det historiesyn, der allerede blev udkastet i Verdens Krønike 1812, uddybedes i Verdens Krønike 1814 og 1817, og som i forordet til Haandbog i VerdensHistorien 1833 erklæredes for det eneste guddommelig sande og eviggældende. Det ligger ogs̊̊ bag hans folkelige skrifter og sange.

Det er altså på Grundtvigs forhold til syndefaldet, den kristelige og dermed teologiske forsvarlighed af hans tænkning må prøves, og hvorefter den må vurderes. - Og dette lader sig meget vel gøre under læsningen af Grells disputats. Derpå beror dens værdi.

Men den første udbygning af Grundtvigs menneskeopfattelse - som netop går ud på at forklare oprindelsen til de forskellige folk på denne jord - har netop sit udgangspunkt i syndefaldet (som Grundtvig var mere optaget af i 1814 end i 1844-65). Ikke det i paradiset, men det, som Bibelen skildrer $i$ fortællingen om Babelstårnet, hvilket ses af Verdens Krønike 1814 og bogen "Europa, Frankrig og Napoleon" (1815), som Grell efter min mening har gjort for lidt ud af i "Skaberånd og folkeånd". - I Verdens Krønike 1814 betragter Grundtvig fortællingerne om Syndfloden og Babelstårnet som en fortsættelse af syndefaldet i paradiset. Syndfloden førte til en næsten fuldstændig udslettelse af den natur, Gud havde skabt, og bygningen af Babelstårnet af det oprindelige sprog, som Gud havde talt til Adam og Eva i, og som kun udtrykte sande forestillinger og tanker. Men ødelæggelsen var ikke fuldstændig. Ved sin pagt med Noah bevarede Gud de semitiske, hamitiske og jafetiske folk, og ved sin forvirring af det oprindelige sprog, som menneskene havde misbrugt til endnu engang at sæette sig i Guds sted - skønt de langtfra havde opnået deres bestemmelse: at ligne Gud - ødelagde Gud ikke fuldstændigt de oprindelige, sande forestillinger og ord. Men han lod menneskene holde sig til de forestillinger, de havde forkærlighed for, og således opstod de forskellige sprog, som stadig kendetegner de forskellige folk.

Det er denne sprogforvirring, Grundtvig tænker sig ophævet for en kort tid ved pinseunderet, hvor de forskelligste folk på én gang forstod hinanden og talte det samme sprog om "Guds store gerninger" i 2. kapitel af Apostlenes Gerninger. Og det er dette perspektiv, Grundtvig taler om i slutningen af sin pinsesalme "I al sin glans nu stråler solen": det er Helligånden, der ved Jesu evangelium gennem tidens løb vil ophæve sprogforvirringen og genskabe folkenes evne til at forstå hinanden. Men endnu befinder de sig på et ufuldkomment stadium af denne historiske udvikling.

Denne geniale konception af folkenes og sprogenes udvikling har Grundtvig altså nedskrevet og udgivet i dens ældste form i årene 1814-15, dvs. samtidig med de begivenheder i Danmarks og Europas historie, der fulgte på Napoleons tilbagetog fra Rusland: Norges adskillelse fra Danmark ved freden i Kiel januar 1814 og Napoleons endelige nederlag ved Waterloo i juni 1815. (De fantasier om 
Napoleon som "Guds vidunderlige Redskab" i VK 1812 eller som forløber for Antikrist i "En mærkelig Spaadom" i 1814, som han måtte forsvare mod H.C. Ørsted i 1815, har i for høj grad overskygget de blivende resultater i Grundtvigs tankeverden.) Han måtte i disse år - fra 1811 til 1815 - opgive tanken om at blive en ny reformator, at kalde studenterne til kamp mod Sverige, at betragte sig som en profet i Det gamle Testamentes forstand og - smerteligst - at blive universitetslærer eller præst i Norge.

Det var på dette, lavere niveau, Grundtvig befandt sig, da han i Danne-Virke begyndte at opfatte sig som dansker og karakterisere danskheden som et værn mod den tyske idealistiske filosofi. Og det var på dette realistiske fundament, han byggede sin tænkning om kristendommen og menneskelivet. - Hedenskabet $\mathrm{i}$ den nordiske mytologi var langtfra glemt, men tilbagetrængt. I stedet satte han nu de tanker om Danmark som "Nordens Palæstina", samtiden og eftertiden stadig har svært ved at fordøje, men hvis kærne Grell udmærket har forklaret som udtryk for en folkeånd, der er et - vel at mærke ufuldkomment, men ikke tilstrækkelig selvbevidst - billede af Guds skaberånd, ligesom den menneskelige poesi er det. Herom kan man læse meget i Grells afhandling, der fører frem til to uudgivne Grundtvig-manuskripter fra 1865 , som han refererer og kommenterer, men som snarest bør udgives.

Det fremgår af denne afsluttende fase $\mathrm{i}$ udviklingen af Grundtvigs tanker om folk og folkelighed, at han meget vel er opmærksom på den fare, der ligger i at løsrive hans tanker om danskheden fra deres rod $\mathrm{i}$ den mosaisk-kristelige anskuelse af menneskelivet, som her er fremhævet. Det vil føre til den afsporing af hans tanker, han selv kalder "Æventyrlighed", dvs. virkelighedsfremmed fantasteri. - Men det er denne fare, langtfra alle i hans omgivelser forstod. Man kunne ønske, at Helge Grell endnu tydeligere havde fremhæevet denne fare $\mathrm{i}$ Grundtvigs opfattelse af folk og folkelighed, end det her er sket. - Er forankringen i kristendommen et tilstrækkelig sikkert værn mod en sådan afsporing af Grundtvigs tanker om folk og folkelighed? Grundtvigs svar er ja. 